\title{
Managing Phosphorus in Polish Agriculture - Production and Environmental Aspects
}

\author{
Jerzy Kopiński ${ }^{1}$, Beata Jurga ${ }^{2 *}$ \\ ${ }^{1}$ Institute of Soil Science and Plant Cultivation, State Research Institute in Puławy, \\ Department of Systems and Economics of Crop Production, \\ Czartoryskich 8 St., 24-100 Puławy, Poland \\ ${ }^{2}$ Institute of Soil Science and Plant Cultivation, State Research Institute in Puławy, \\ Department of Plant Nutrition and Fertilization, \\ Czartoryskich 8 St., 24-100 Puławy, Poland
}

Received: 11 April 2016

Accepted: 11 July 2016

\begin{abstract}
Phosphorus (P) is an essential building block of life. It is an irreplaceable part of agriculture, as there is no substitute for its use for producing food and feed. The objective of $\mathrm{P}$ fertilization is to add an adequate (in regard to soil test P) amount of $\mathrm{P}$ to produce an economical yield. Unbalanced P management leads to $\mathrm{P}$ wastage, lower cost-effectiveness of production, and water quality impairment. The aim of this paper is to analyze the structure and trends in the consumption of phosphorus mineral fertilizers and to draw gross phosphorus balance in Poland (NUTS level 1) and by regions (NUTS level 2). In Poland, P for agriculture is mainly applied as a compound fertilizer, among which diammonium phosphate represents the greatest share. Average P consumption rate in Poland has declined slightly since 2008, currently reaching $24.4 \mathrm{~kg}$ $\mathrm{P}_{2} \mathrm{O}_{5} \cdot \mathrm{ha}^{-1}$ UAA. The differences in intensity of farming, measured by the consumption of PMF, reached more than $200 \%$, and this differentiation has intensified over the years. The polarization of Polish agriculture is also confirmed by GPB outcome, as differences between provinces are in the range of $-1.9 \mathrm{~kg} P \cdot \mathrm{ha}^{-1}$ UAA in Małopolskie to $7.7 \mathrm{~kg} \mathrm{P} \cdot \mathrm{ha}^{-1} \mathrm{UAA}$ in the Wielkopolskie region. The differences in crop and animal production in Poland are largely conditioned by both organizational and production management, which conjointly affect agricultural phosphorus use efficiency.
\end{abstract}

Keywords: management of phosphorus, mineral fertilizers, soil resources, phosphorus balance, regional differentiation

\section{Introduction}

Phosphorus (P) is an essential building block of life. It naturally occurs in the environment as organic and mineral compounds, mostly as orthophosphates. $\mathrm{P}$ is introduced

*e-mail: bjurga@iung.pulawy.pl into agriculture as phosphorus mineral fertilizers (PMF), manures, and other organic sources such as digestate and sewage sludge. It is an irreplaceable element, as there is no substitute for its use in animal feed and fertilizer. Sustainable $\mathrm{P}$ management is vital as $\mathrm{P}$ is one of the most yield-forming factors for determining production capacity, including varietal improvement. In addition, when used efficiently, losses are minor and almost irrelevant [1-2]. 
In an intensive farming system, relatively high $\mathrm{P}$ doses are applied but plants take up significant $P$ amounts. However, successive over-fertilization may lead to a surplus of $\mathrm{P}$ in soil, above plant needs, exceeding soil sorption capacity, and resulting in $\mathrm{P}$ losses through leaching, and soil and wind erosion. Elevated risk of P losses when fertilization is applied exists especially on soils with naturally high P content. Unsustainable P management is detrimental even though $\mathrm{P}$ cannot be destroyed, but it can be scattered and transformed and thus is difficult to utilize in agricultural production. Scattering of phosphorus beyond the agricultural ecosystem acts as a potential environmental hazard [3] as increased $\mathrm{P}$ concentrations in water bodies are a trigger for eutrophication [4-5]. On the contrary, applying low doses of $\mathrm{P}$ fertilization to soil with a deficit of available $\mathrm{P}$ in plants may lead to depletion of soil $\mathrm{P}$ reserves as aluminum, iron, calcium, and magnesium compounds [6]. Consequently, $\mathrm{P}$ is becoming a limiting factor, decreasing yield and both technical and economic efficiency of fertilization [7]. The objective of phosphorus fertilization should therefore be to add an adequate amount of $\mathrm{P}$ to produce the economic yield with regards to plant needs [6].

The main raw materials for PMF production are phosphate rock and guano [8]. P resources are relatively abundant globally and reserves are significant, but several factors exist that imply that for EU countries issues related to P supply should be monitored. Reserves are located in politically unstable countries, which creates the risk of volatile prices, an example of which was the situation in the UE in 2008 when prices of phosphorus rock rose by $700 \%$ in a little over a year. Within the European continent, reserves are limited and insufficient to cover domestic demand, and in addition the potential to use recycled $\mathrm{P}$ from alternative sources, including sludge, digestate, and human urine, although growing, is still low. Last but not least, although efforts have been taken to minimize $\mathrm{P}$ consumption, there is no reason to expect a real reduction of $\mathrm{P}$ demand in the EU as nearly $90 \%$ of it is consumed as fertilizers, and according to WHO, the demand for food will continue to increase over the next years [after: 9]. All this together explains why phosphorus has been included in the list of critical raw materials [10].

Sustainable P management is then crucial for obtaining long-term effective agricultural productivity and for maintaining the good status of the environment. P balances are useful tools for assessing fertilizer need and also are an important element of an informational system on farms, providing information on the actual surplus of nutrients as well as on agri-environmental factors [11] and decision support, affecting the shape of global agricultural and environmental policies [12]. Adoption and use of the unified balance approach allows for successful evaluations and comparisons at different levels of agricultural management: farms, regions, and countries. One of the most commonly used methodologies is gross phosphorus balance (GPB) as recommended by [3] and Eurostat [13]. The prime aim of the GPB is to estimate the net loading of the soil with nutrients. This explains why all nutrients that enter the soil are recorded as inputs. GPB reveals its full usefulness as a tool for agri-environmental $\mathrm{P}$ management when compared with soil $\mathrm{P}$ test results and water body quality, as surplus does not necessarily correspond to nutrient losses directly. The aim of this work is to evaluate phosphorus management in Poland through analysis production and consumption of PMF crossed with calculated gross phosphorus balance for Poland (NUTS level 1) and by regions (NUTS level 2).

\section{Materials and Methods}

All analyses were performed using the desk study approach. Input data originated from four types of sources, the most relevant of which were the reports of the Central Statistical Office (CSO) [14-22], which collects data based on surveys conducted in all agricultural holdings of legal persons and organizational units plus a sample of private farms. The following data were obtained from national statistics: consumption of PMF, animal density, sown and crop areas, and yield and crop production. Other sources of data include reports of the Institute of Agricultural and Food Economics - National Research Institute [23], publications of the International Fertilizer Industry Association Fertilizers Europe [24], and relevant scientific papers [8, 25-27]. The balance of mineral phosphorus fertilizers was performed for 2006-13. Long- (1993-2015) and shortterm (2008-15) trends in PMF consumption were determined. Regional differentiation of intensity of agricultural production was measured for 2012-15 by employing an amount of used PMF as a reference. Average values of the latest three years were taken to smooth seasonal effects. The efficiency of plant productivity was expressed as a cereal unit (one cereal unit is equal to $100 \mathrm{~kg}$ of grain). To evaluate the environmental impact of phosphorus management a GPB was calculated for 2002-14 using the OECD and Eurostat approach [3, 13, 25, 28]. Phosphorus balance (soil surface balance) is calculated as the difference between the total quantity of phosphorus entering the soil (including atmospheric deposition [29]) and the quantity of phosphorus leaving the agricultural area (UAA) annually (Fig. 1). UAA is limited to the agricultural area kept

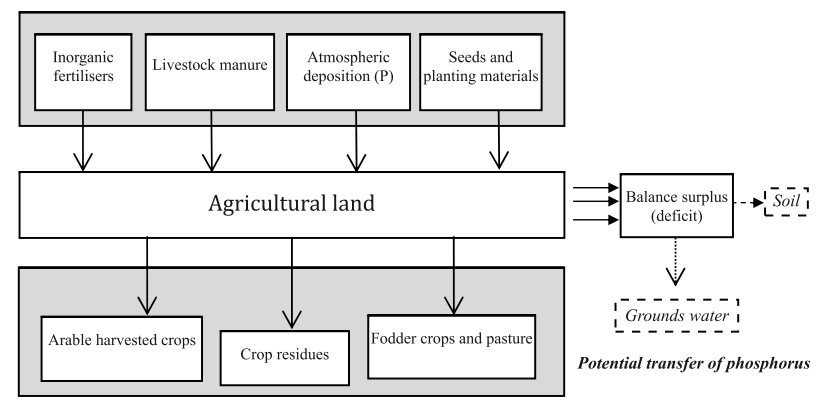

Figure 1. The main elements in the OECD gross phosphorus balance calculation. Source: OECD, 2006: Environmental Indicators for Agriculture. Publications Service. Paris, France, vol. 4, chapter 3. [3] 
in good agricultural condition maintained in accordance with EU norms as defined in the regulations of the minister of agriculture and rural development [30]. The study distinguished different types of fertilizers in accordance with the definitions contained in the regulations (EC) No. 2003/2003 [31].

The scope of the research was limited by data availability and level of data aggregation. As a reference value for comparing the results of each voivodship we used an average value calculated for the whole territory of Poland.

\section{Results and Discussion}

\section{Production and Structure of Consumption of Phosphorus Mineral Fertilizers}

PMFs are manufactured mainly from phosphate rock and guano, and nowadays PMF production is concentrated in world regions where $\mathrm{P}$ deposits are mined. This arises from the fact that the phosphoric acid trade and transport of ready-made fertilizers are more cost-effective than the trade of raw materials. World production of PMF is located in more than 60 countries and exceeds $44 \mathrm{Tg}$ of phosphoric acid (expressed as $\mathrm{P}_{2} \mathrm{O}_{5}$ ) Since 2002, China has been the undisputed leader in the production of phosphate fertilizers, mining $40 \%$ of the globally extracted phosphate rock of total volume of $199 \mathrm{Tg}$ in 2014 [20, 27]

Phosphorus is supplied to agricultural land by broadcasting mineral fertilizers in the form of natural rock phosphate, superphosphates, and mostly compound fertilizer, whose share in world production of PMF increased in 2012 by up to $81 \%$ [27], whereas straight fertilizers (superphosphate) had little - namely an $18 \%$ share in the global market of PMF [20]. Production of diammonium phosphate predominated among compound fertilizers. The productivity potential of PMF for Polish industry reaches up to more than $700 \mathrm{Gg}$ of $\mathrm{P}_{2} \mathrm{O}_{5}$ (Table 1), completely covering domestic demand and allowing export of up to $100 \mathrm{Gg}$

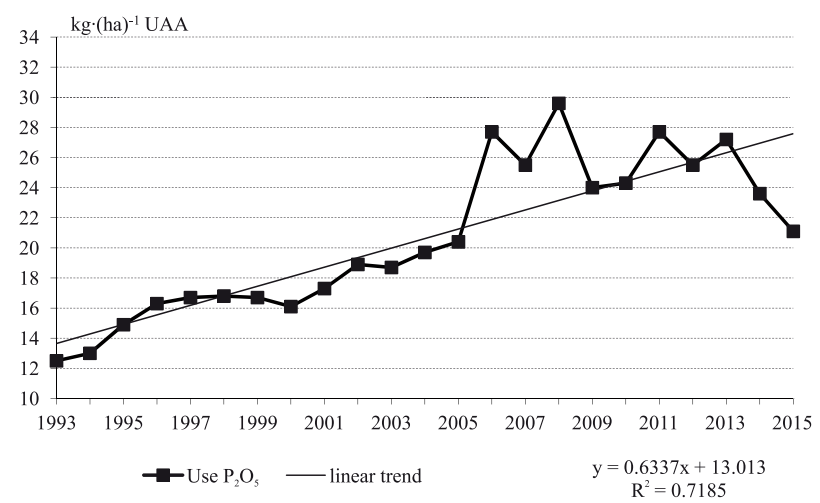

Fig. 2. Long-term (22 years) linear trend of phosphorus consumption in mineral fertilizers in Poland. Source: own calculation based on CSO data $[20,22]$.

$\mathrm{P}_{2} \mathrm{O}_{5}$ in previous years. The biggest collapse of the county's production of PMF occurred in 2009 as a result of the financial crisis of 2007-08. Following rapid market recovery, since 2011 a gradual drop in PMF production has been observed, reaching as low as $372 \mathrm{Gg} \mathrm{P}_{2} \mathrm{O}_{5}$ According to Igras and Fotyma [6], there are five main producers of PMF in Poland: Grupa Azoty Zakłady Chemiczne Police SA, Zakłady Chemiczne Luwena, Zakłady Chemiczne SIARKOPOL in Tarnobrzeg, Zakłady Fosfan in Szczecin, and in Gdańskie Zakłady Nawozów Fosforowych Fosfory.

The level of concentration of crop production along with the relation of demand-supply affected the size of production and price level of PMF [6, 27]. An analysis of long trends demonstrated that consumption of PMF in Poland has slowly increased since 1990 (Fig. 2), and annual growth of PMF is estimated as $0.7 \mathrm{~kg} \mathrm{P}_{2} \mathrm{O}_{5} \cdot \mathrm{ha}^{-1} \mathrm{UAA}$.

However, the last 10 years have seen significant fluctuations of PMF consumption. After accelerating the pace of consumption, the 2008 economic crisis resulted in a drop to 2005 levels. The actual average consumption rate of $\mathrm{P}$ is $24.4 \mathrm{~kg} \mathrm{P}_{2} \mathrm{O}_{5} \cdot \mathrm{ha}^{-1} \mathrm{UAA}$ for $2012-15$ and this is an effect of a weak short-term declining trend that started in 2008

Table 1. Balance of mineral phosphorus fertilisers in Poland in terms of pure ingredients $\left(\mathrm{P}_{2} \mathrm{O}_{5}\right)$.

\begin{tabular}{|c|c|c|c|c|c|c|c|c|}
\hline \multirow{2}{*}{ Years } & \multicolumn{4}{|c|}{ Resource $(\mathrm{Gg})$} & \multicolumn{4}{c|}{ Use $(\mathrm{Gg})$} \\
\cline { 2 - 9 } & Total & Production & Imports & Decrease in stocks & Total & Domestic supplies & Exports & Increase in stocks \\
\hline 2006 & 677.2 & 595.1 & 66.8 & 5.3 & 677.2 & 510.0 & 167.2 & - \\
\hline 2007 & 730.5 & 649.5 & 77.8 & 3.2 & 730.5 & 558.7 & 171.8 & - \\
\hline 2008 & 594.8 & 535.6 & 59.2 & - & 594.8 & 376.8 & 163.1 & 54.9 \\
\hline 2009 & 344.3 & 241.5 & 51.6 & 51.2 & 344.3 & 297.9 & 46.4 & - \\
\hline 2010 & 556.5 & 486.4 & 69.3 & 0.8 & 556.5 & 415.8 & 140.7 & - \\
\hline 2011 & 606.6 & 537.5 & 66.2 & 2.9 & 606.6 & 497.6 & 109.0 & - \\
\hline 2012 & 555.2 & 473.9 & 81.3 & - & 555.2 & 453.2 & 102.0 & - \\
\hline 2013 & 441.7 & 371.7 & 70.0 & - & 441.7 & 341.7 & 1000 & - \\
\hline
\end{tabular}

Source: own study based on data: [14-18, 27]. 


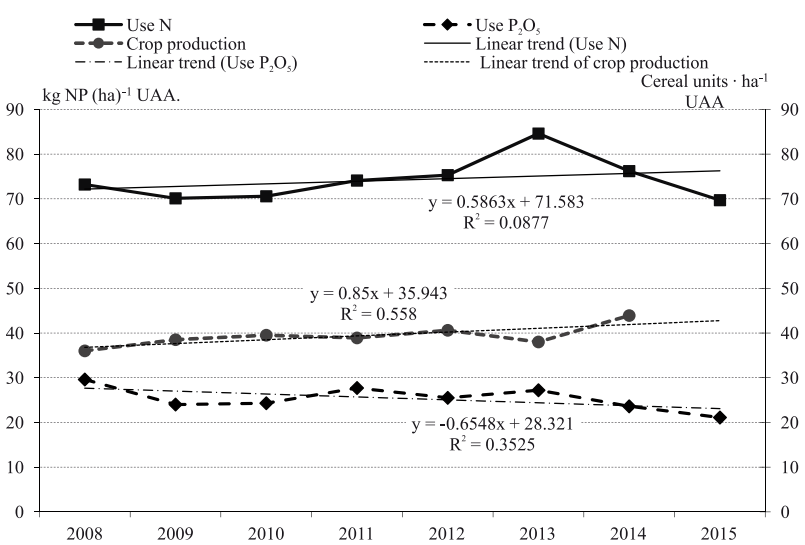

Fig. 3. Short-term (8 years) linear trend of nitrogen $(\mathrm{N})$ and phosphorus $\left(\mathrm{P}_{2} \mathrm{O}_{5}\right)$ consumption in mineral fertilizer and crop production (expressed as cereal units) in Poland. Source: own calculation based on CSO data [14-22].

(Fig. 3). This trend is consistent with the current situation occurring in the vast majority of EU countries.

As reported by Matyka [32], 23 EU countries have reported reduced consumption of $\mathrm{P}$. An average decline of consumed $\mathrm{P}$ is $0.8 \mathrm{~kg} \mathrm{P} \mathrm{O}_{5} \mathrm{~kg} \cdot \mathrm{ha}^{-1} \cdot \mathrm{y}^{-1}$ in 2002-10 for the EU-27. The reversal of the upward trend in consumption of $\mathrm{P}$ and deceleration of the high consumption of nitrogen in mineral fertilizers in the last eight years in Poland [33] is favorable because, while maintaining productivity growth (expressed as units of grain), both factors have led to improvement in $\mathrm{P}$ use efficiency.

Unfortunately, this phenomenon is accompanied by extending the N:P ratio leading to increased acidification of arable land, the biggest contributor of which is intensified nitrogen fertilization [34].

In 2012-15 the size of the $\mathrm{N}: \mathrm{P}$ ratio was 1:0.32, and the share of $\mathrm{P}$ in the structure of the consumption of mineral fertilizers (NPK) did not exceed 19\%, while nitrogen accounted for as much as $58 \%$ of it (Fig. 4). This phenomenon is disadvantageous and requires further monitor-

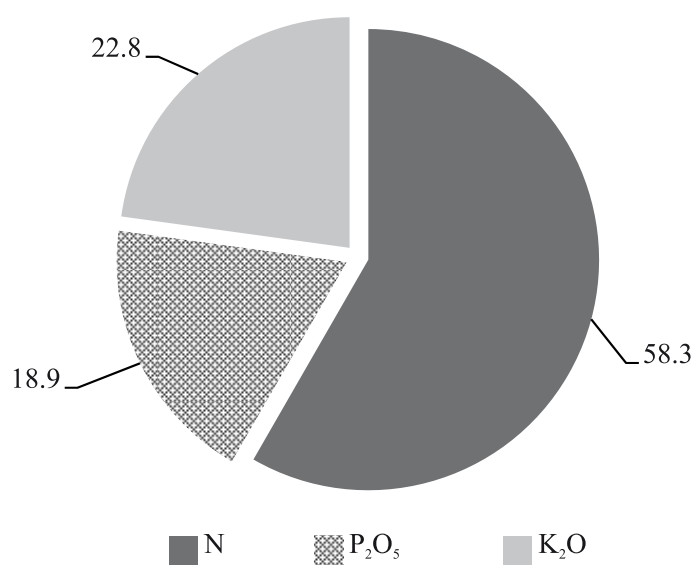

Fig. 4. Share of mineral fertilizers (in \% NPK) in Poland in 2012-15. Source: own calculation based on basic CSO data [14-20].

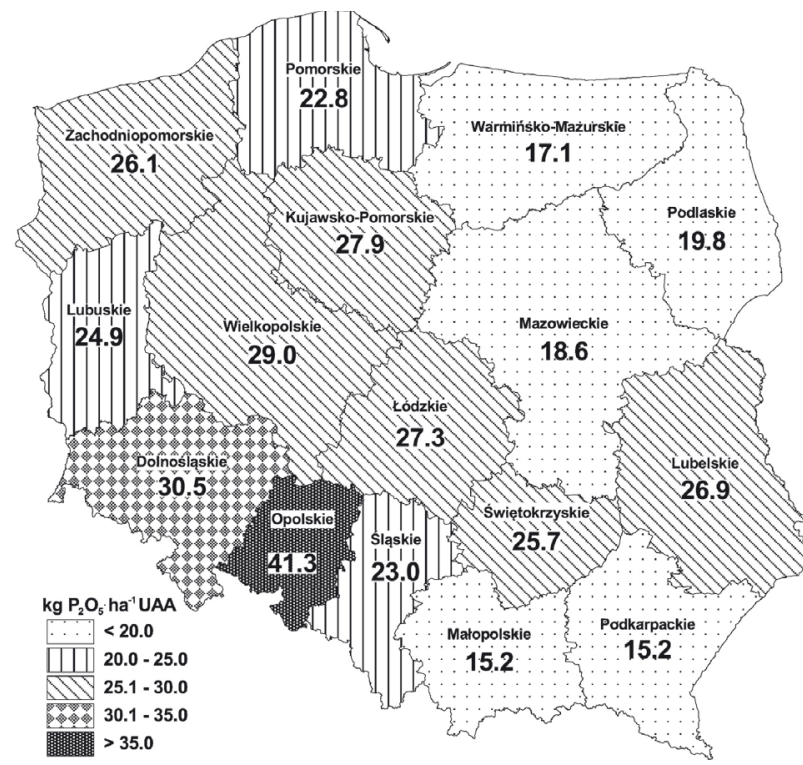

Fig. 5. The level of phosphorus consumption in mineral fertilizers in Polish voivodships in 2012-15. Source: own calculation based on CSO data [14-22]. Graphic design by E. Wróblewska.

ing because a resulting decrease in nitrogen use efficiency leads to the impoverishment of the soil in the form of available phosphorus and potassium ions [35]. According to CSO data [19], 31\% of soils in Poland in 2011-14 were characterized by very low and low abundance of available $\mathrm{P}$ forms. On these soils, it would be advisable to increase $\mathrm{P}$ application rates in relation to the needs of cultivated crops. In respect to this, Kopiński and Matyka [24] estimated that advisable increases in $\mathrm{P}$ fertilization should reach $34 \mathrm{~kg} \mathrm{P}_{2} \mathrm{O}_{5} \cdot$ ha $^{-1}$ UAA in 2025.

One of the many characteristics of Polish agriculture is a large regional variation of natural conditions and intensity of production [36-39]. This explains why average values of fertilizer indicators inadequately reflect the factual situation and changes occurring within the country and more precise spatial accuracy would be recommended. Consumption of $\mathrm{P}$ from PMF is greatest in the western and southwestern parts of the country, and the least (except for Lubelskie Voivodship) in the eastern part (Fig. 5). The difference between the leading voivodeship (i.e., Opolskie at $41.3 \mathrm{~kg} \mathrm{P} \cdot \mathrm{ha}^{-1} \mathrm{UAA}$, and Małopolskie, and Podkarpackie at $15.2 \mathrm{~kg} \mathrm{P} \cdot \mathrm{ha}^{-1} \mathrm{UAA}$ ) is above $200 \%$.

Additionally, the state of soil fertility represents a wide variation in different regions within the country as exemplified by negative soil valuation for P (appointed by the percentage of soils with $\mathrm{P}$ content less than $4.36 \mathrm{P} \cdot 100 \mathrm{~g}^{-1}$ soil), which ranged widely - from $19 \%$ in Wielkopolska up to $57 \%$ in Małopolskie (Fig. 6) [19]. Therefore, maintaining extensive $\mathrm{P}$ fertilization in the voivodships with a significant share of soil with agricultural phosphorus deficit leads to a considerable reduction of soil production potential, since $P$ scarcity is becoming a limiting factor for plant and animal production. The scale of this problem is well illustrated by the fact that in the voivodships with the lowest level of $\mathrm{P}$ fertilization (i.e., 


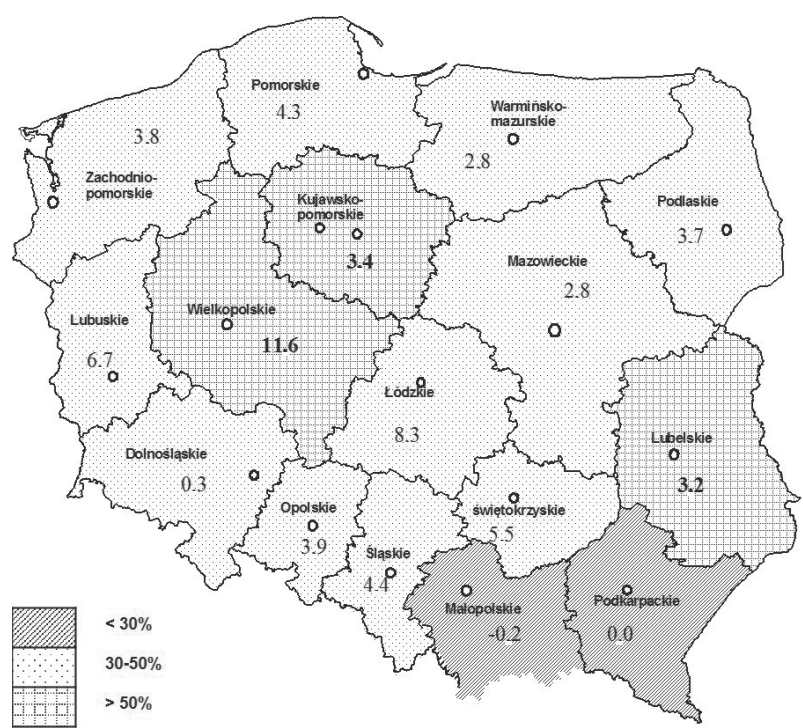

Fig. 6. Negative soil valuation for phosphorus content appointed as the percentage of soils with $\mathrm{P}$ content below $4.36 \mathrm{P} \cdot 100 \mathrm{~g}^{-1}$ soil [26].

Małopolskie and Podkarpackie), only 2\% of households with more than 1 ha of agricultural land spread straight PMF [23].

\section{Gross Phosphorus Balances}

\section{NUTS level 1}

Gross phosphorus balance (GPB) is one of the most important tools for assessing the impact of agricultural production on the environment as the risk of scattering of nutrients (phosphorus compounds) beyond the borders of the agricultural ecosystems can be approximately estimated by a just budget outcome. With regard to that, GPB testifies to the correctness of a nutrient's economy and is an important indicator of sustainability [38]. The usefulness of GPB results in practice increase in juxtaposition with the state of soil fertility, groundwater quality, and yield measurements. Significant surpluses of GPB can increase soil fertility, but also may create a risk of deterioration of ground and surface waters. It is also expensive to combat an excess of $\mathrm{P}$, as it can be removed only through remediation techniques [40]. In contrast, a negative $\mathrm{P}$ balance may impair soil fertility and indicate the risk of limiting productivity potential [3]. Ideally, the balance should be close to zero. Taking into account unfavorable soil P content, atmospheric deposition for Polish territory, and P surplus required to maintain and rebuild soil reserves, an optimal GPB balance for Polish territory is currently estimated as not greater than $2 \mathrm{~kg} \mathrm{P} \cdot \mathrm{ha}^{-1} \mathrm{AL}[7,25]$.

A mean GPB calculated for Poland for 2012-14 revealed positive $\mathrm{P}$ balance with a surplus on average of $2.5 \mathrm{~kg} \mathrm{P} \cdot \mathrm{ha}^{-1}$ UAA (Table 2), which is close to the optimum suggested by experts. In general, $\mathrm{P}$ balance across the country underwent a gradual decrease over the last decade (excluding Wielkopolska, Łódzkie, Świętokrzyskie, and Opolskie voivodships) with an average reduction of $-0.2 \mathrm{~kg} \mathrm{P} \cdot \mathrm{ha}^{-1}$ UAA. Our study suggests that a decrease in PMF consumption and an increase in crop productivity (resulting in increased $\mathrm{P}$ removal) are together factors explaining lower GPB in recent years (Fig. 3). Most P in Polish agriculture is brought into the soil as mineral fertilizers and a slightly smaller amount as manures (see also: [26]), for this reason, a lower GPB could also be explained by the reduced pool of $\mathrm{P}$ supplied with manure as the downward trend of a livestock population number is currently observed [21, 24-25]. The largest output occurs in the harvesting of major crops. These quantities are generally more than double than P removed with feed crops and in plant by-products.

\section{NUTS Level 2}

The identified $\mathrm{P}$ surplus is necessary to maintain soil productivity and combined with observed decreasing trend could not indicate any environmental risk. However, an analysis of regional differentiation at NUTS level 2 reveals that balance varies significantly between voivodships. The lowest balance was noticed in Małopolskie and Dolnośląskie, where on average 1.9 and $1.5 \mathrm{~kg}$ P.ha- ${ }^{-1} \mathrm{UAA}$ respectively were removed from the field (negative balance!). In contrast, in Wielkopolskie surplus reached as much as $7.7 \mathrm{~kg} \mathrm{P} \cdot \mathrm{ha}^{-1}$ UAA and in Łódzkie $6.2 \mathrm{~kg} \mathrm{P} \cdot \mathrm{ha}^{-1}$ UAA. The differences in balance between regions reached more than $200 \%$ and the results did not correspond directly with negative soil valuation for P. Wielkopolskie was one of four voivodships (next to Łódzkie, Świętokrzyskie, and Opolskie) characterized by increased $\mathrm{P}$ balances between 2002-04 (Table 2). This might be attributed to recycling $\mathrm{P}$ from manure as input from manures was the highest in the country (12.6 kg P.ha- $\left.{ }^{-1} \mathrm{UAA}\right)$, and additionally an increasing trend in animal production is observed currently in Wielkopolskie and Opolskie [21]. The greatest P accumulation took place in Lódzkie, where the balance was $3.8 \mathrm{~kg} \mathrm{P} \cdot \mathrm{ha}^{-1}$ UAA greater than in 2002-04, which could be, at least partially, attributed to higher-than-average $\mathrm{P}$ input in PMF. The amount of $\mathrm{P}$ applied with $\mathrm{PMF}$ was $13.1 \mathrm{~kg} \mathrm{ha}^{-1} \mathrm{UAA}$, where on average in Poland it is $11.4 \mathrm{~kg}$ P.ha-1 $\mathrm{hAA}^{-1}$. Łódzkie is a region where positive GPB and the observed surplus can be beneficial for equalizing soil conditions of agricultural production if they occur in fields with $\mathrm{P}$ deficits. This, unfortunately, cannot be clearly stated because of the limitations of spatial data resolution. The observed diversity is largely conditioned by management and production factors, which also affect the use efficiency of $\mathrm{P}$ in agriculture. The Wielkopolska case confirms that pairing positive surplus with negative soil valuation for $\mathrm{P}$ is a challenge in Poland since this region, as well as Kujawsko-Pomorskie and Lubuskie, stands out from the rest of the country due to its lowest share of soils with a low and very low content of available phosphorus in soils [19]. This indicates that P management in this area may pose a hazard in maintaining good environmental status of soil and water. This appraisal is not suitable for the evaluation of $\mathrm{P}$ management in the Lódzkie region 
Table 2. Gross phosphorus balances in Polish voivodships in $\mathrm{kg} \mathrm{P} \cdot \mathrm{ha}^{-1} \mathrm{UAA}$.

\begin{tabular}{|c|c|c|c|c|c|c|}
\hline \multirow{4}{*}{ Voivodeships } & \multicolumn{5}{|c|}{ Values of phosphorus balance elements, 2012-14 } & \multirow{4}{*}{$\begin{array}{c}\text { Change of } \mathrm{P} \text { balance } \\
\text { in reference period } \\
\text { to } 2002-04\end{array}$} \\
\hline & \multirow{3}{*}{ Total } & \multicolumn{2}{|c|}{ Input } & \multirow{3}{*}{ Output } & \multirow{3}{*}{ Balance } & \\
\hline & & \multicolumn{2}{|c|}{ in fertilization: } & & & \\
\hline & & mineral & manure & & & \\
\hline Dolnośląskie & 17.7 & 14.1 & 2.8 & 19.2 & -1.5 & -0.4 \\
\hline Kujawsko-pomorskie & 20.4 & 12.1 & 7.5 & 19.5 & 0.9 & -1.0 \\
\hline Lubelskie & 17.2 & 12.4 & 4.0 & 15.1 & 2.1 & 0.0 \\
\hline Lubuskie & 18.1 & 12.4 & 5.0 & 15.1 & 3.0 & -2.9 \\
\hline Łódzkie & 21.8 & 13.1 & 7.8 & 15.5 & 6.2 & 3.8 \\
\hline Małopolskie & 12.9 & 6.5 & 5.7 & 14.8 & -1.9 & -5.6 \\
\hline Mazowieckie & 17.3 & 8.8 & 7.7 & 14.9 & 2.5 & -1.6 \\
\hline Opolskie & 25.2 & 19.5 & 4.8 & 24.0 & 1.2 & 1.3 \\
\hline Podkarpackie & 11.8 & 7.1 & 3.9 & 12.3 & -0.6 & -3.2 \\
\hline Podlaskie & 18.0 & 9.3 & 8.0 & 15.5 & 2.5 & -1.7 \\
\hline Pomorskie & 17.5 & 10.9 & 5.8 & 15.6 & 1.9 & -5.5 \\
\hline Śląskie & 20.0 & 10.9 & 8.3 & 16.0 & 4.0 & -1.1 \\
\hline Świętokrzyskie & 17.7 & 11.7 & 5.2 & 13.5 & 4.2 & 2.4 \\
\hline Warmińsko-mazurskie & 15.9 & 7.9 & 7.3 & 15.0 & 0.9 & -0.3 \\
\hline Wielkopolskie & 27.0 & 13.5 & 12.6 & 19.3 & 7.7 & 1.8 \\
\hline Zachodniopomorskie & 16.9 & 13.2 & 2.8 & 15.8 & 1.1 & 0.0 \\
\hline Poland & 19.0 & 11.4 & 6.8 & 16.5 & 2.5 & -0.2 \\
\hline
\end{tabular}

Source: own study based on [14-21, 29].

characterized by $36 \%$ of soils with $\mathrm{P}$ content less than 10.0 $\mathrm{P}_{2} \mathrm{O}_{5} \cdot 100 \mathrm{~g}^{-1}[26]$.

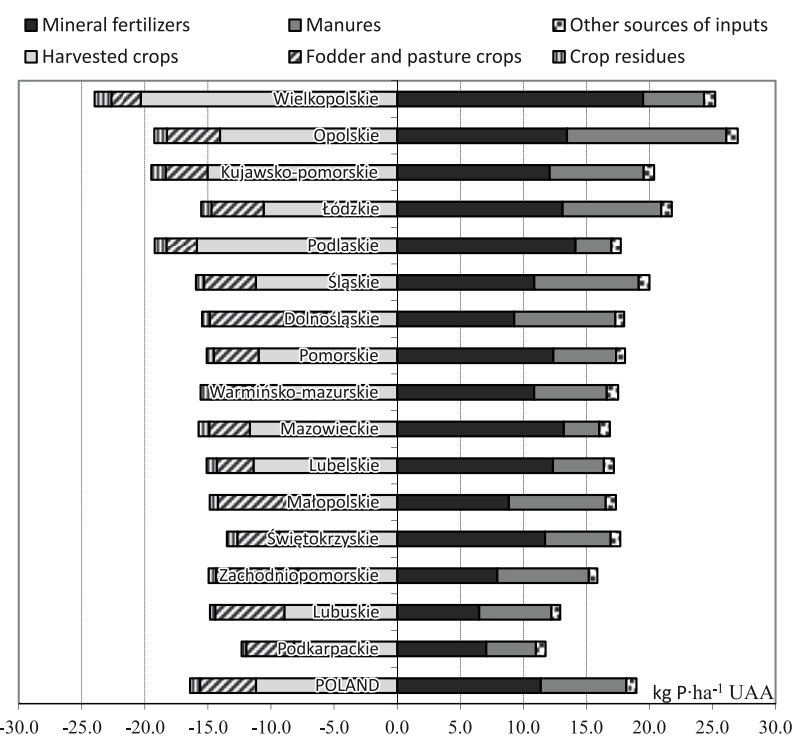

Fig. 7. The quantitative structure of $P$ inputs and outputs of gross phosphorus balance in individual Polish voivodships in 2012-14. Source: own study based on [17-21, 23].
GPB for two southeastern provinces, Podkarpackie and Małopolskie, revealed that removal of $\mathrm{P}$ by crops was not fully compensated for by $\mathrm{P}$ fertilizer, resulting in a deficit of about $1.9 \mathrm{~kg} \mathrm{P} \cdot \mathrm{ha}^{-1} \mathrm{UAA}$. It is alarming as the negative GPB is particularly unfavorable on soils with a low abundance of this nutrient, and according to researchers, over the last few years a trend of negative balance in these two provinces has been maintained [28, 35]. This has led to a serious limitation to fully exploiting the potential agricultural production of these regions. Negative GPB was also found in Dolnośląskie, although it is attributed to the high soil productivity and relatively good $\mathrm{P}$ supply in previous years so it is not as alarming, but nevertheless it should be avoided and carefully monitored in coming years.

The biggest $\mathrm{P}$ turnover (sum of the $\mathrm{P}$ input and output) is observed in Wielkopolskie, Opolskie, and $\mathrm{Ku}-$ jawsko-Pomorskie (Fig. 7) at 49.1, 46.3, and $39.8 \mathrm{~kg}$ $\mathrm{P} \cdot \mathrm{ha}^{-1}$ UAA, respectively. Less intensive P management, exemplified by smaller $\mathrm{P}$ turnover, was detected in regions with extensive agricultural production, namely in southeastern Poland (in Podkarpackie $24.2 \mathrm{~kg} \mathrm{P} \cdot \mathrm{ha}^{-1} \mathrm{UAA}$ and Świętokrzyskie $\left.31.2 \mathrm{~kg} \mathrm{P} \cdot \mathrm{ha}^{-1} \mathrm{UAA}\right)$, but also in Lubuskie at $27.7 \mathrm{~kg} \mathrm{P} \cdot \mathrm{ha}^{-1} \mathrm{UAA}$. 


\section{Conclusion}

The productivity potential of PMF in Polish industry reaches app. $700 \mathrm{Gg} \mathrm{P}_{2} \mathrm{O}_{5}$ (Table 1), has completely covered domestic demand, and has allowed us to export up to $100 \mathrm{Gg}_{2} \mathrm{O}_{5}$ in previous years. However, since 2011 the decline in production of PMF in Poland to the level of $372 \mathrm{Gg} \mathrm{P}_{2} \mathrm{O}_{5}$ is observed as a consequence of the global economic crisis and the worldwide concentration of production processes. Large fluctuations of consumption of PMF in Poland were noticed in the last decade, although consumption of PMF in Poland demonstrates a long-term upward trend since the early 1990s. The current average consumption rate of $\mathrm{P}$ is $24.4 \mathrm{~kg} \mathrm{P}_{2} \mathrm{O}_{5} \cdot \mathrm{ha}^{-1} \mathrm{UAA}$, but a weak short-term downward trend of consumption of PMF has been noticed since 2008. Compound fertilizers are a widespread source of P. Among them, diammonium phosphate is the most commonly used. Our analysis revealed that Polish agriculture is experiencing deepening regional differentiation of agriculture intensity, expressed as the level of consumption of PMF, and differences observed among voivodships are more than double. This polarization is confirmed by gross phosphorus balance results. The observed differences in size of balances between provinces are within of $-1.9 \mathrm{~kg} \mathrm{P}^{-1} \mathrm{UAA}$ in Małopolskie to $7.7 \mathrm{~kg} \mathrm{P} \mathrm{ha}^{-1}$ UAA in Wielkopolska, which are significant, and an effort should be made to reduce the identified differences.

\section{Acknowledgements}

Our research was funded by the Multiannual Program of the Ministry of Agriculture and Rural Development for the Institute of Soil Science and Plant Cultivation - State Research Institute, under tasks 2.1 and 2.2.

\section{References}

1. PONDEL H., RUSZKOWSKA M., SYKUT S., TERELAK $H$. Leaching of fertilizer nutrients from cultivated soils based on Researches carried out by the Institute of Soil Science and Cultivation of Plants. Rocz. Gleb. 42 (3/4), 97, 1991 [In Polish].

2. SYKUT S. Leaching of macroelements from the soils in lysimeters. Fertilizers and fertilization. 4 (5), 18, 2000 [In Polish].

3. OECD. Environmental Indicators for Agriculture. Publications Service. OECD, Paris, 4 (3), 2006.

4. IGRAS J., LIPIŃSKI W. Environmental hazards at different levels of intensity of crop production in regional perspective. Mat. Konf. Nauk. IUNG, Puławy, 141, 2005 [In Polish].

5. BERGSTROM L., KIRCHMANN H., DJODJIC F., KYLLMARK., et all. Turnover and Losses of Phosphorus in Swedish Agricultural Soils: Long-Term Changes, Leaching Trends, and Mitigation Measures. J Environ Qual. 44, 512, 2015.

6. IGRAS J., FOTYMA M. Phosphorus utilization and diffuse losses in agricultural crop production. Chapter in: IGRAS, J., PASTUSZAK, M. (Ed). Temporal and spatial differences in emission of nitrogen and phosphorus from Polish territory to the Baltic Sea. IUNG-PIB Puławy, MIR Gdynia, 161, 2012.

7. FOTYMA M., IGRAS J., KOPIŃSKI J. Production and environmental determinants of fertilizer management in Poland. Studia i Raporty IUNG-PIB. 14, 187, 2009 [In Polish].

8. ZALEWSKI A., IGRAS J. The global market for mineral fertilizers including changes in prices of direct energy and raw materials (2). IERiGŻ-PIB (PW 2011-2014). 37, 102, 2012 [In Polish].

9. COM Communication from the Commission to the European Parliament, the Council, The European Economic and Social Committee and the Committee of the Regions (2013): Consultative Communication on the Sustainable Use of Phosphorus. Brussels, 8.7.2013.

10. European Commission. Report On Critical Raw Materials For the EU. Report of the ad hoc Working Group on defining critical raw materials. May 2014.

11. FABER A. Indicator for sustainable agriculture. Fragm. Agron. 1 (69), 31, 2001.

12. FOTYMA M., KOPIŃSKI J., GŁOWACKI M. Gross nitrogen balance in the European Union based on OECD data OECD. Pam. Puł. 124, 255, 2001 [In Polish].

13. KREMER A.M. Nutrient Budgets EU-27, Norway, Switzerland. Methodology and Handbook. Eurostat/OECD. EC Eurostat, Luxembourg, 2013. (ver. 1.02, 17.05.2013).

14. CSO Central Statistical Office. Gospodarka materiałowa w 2008 roku. Materials management in 2008. Statistical information and elaborations. Warszawa, 2009.

15. CSO Central Statistical Office. Materials management in 2009. Statistical information and elaborations. Warszawa, 2010.

16. CSO Central Statistical Office. Materials management in 2011. Statistical information and elaborations. Warszawa, 2011.

17. CSO Central Statistical Office. Production of industrial products in 2013. Warszawa, 2014 [In Polish].

18. CSO Central Statistical Office. Materials management in 2014. Statistical information and elaborations. Warszawa, 2015.

19. CSO Central Statistical Office. Environmental Protection. 513, Warszawa, 2015. [In Polish]

20. 20. CSO Central Statistical Office. Means of production in agriculture in the 2014/2015 farming year. 42, Warszawa, 2015 [In Polish].

21. CSO Central Statistical Office. Statistical yearbook of agriculture. 193, Warszawa, 2015.

22. CSO Central Statistical Office. Land use and sown area in 2015. 114, Warszawa, 2016 [In Polish].

23. IERiGŻ-PIB. Means of production in agriculture, IERiGŻPIB, ARR, MRiRW, 42, 48, 2015 [In Polish].

24. KOPIŃSKI J., MATYKA M. Forecast of food, farming and fertilizer use 2015-2025. Fertilizers Europe. 1, 114, 2015.

25. KOPIŃSKI J. The development of test methods used to determine the optimal balance of key nutrients (NPK) at NUTS-2 level in 2011 and 2013. A report for the IERiGŻPIB. 22, Puławy, 2014 [In Polish].

26. KOPIŃSKI J., OCHAL P., JADCZYSZYN T. Production and environmental aspects of the management of phosphorus. Studia i Raporty IUNG-PIB. 34 (8), 145, 2013 [In Polish].

27. ZALEWSKI A. The global market for mineral fertilizers including changes in prices of direct energy and raw materials. IERiGŻ-PIB (PW 2011-2014), 107, 122, 2014 [In Polish].

28. KOPIŃSKI J., TUJAKA A. Balance of nitrogen and phosphorus in Polish agriculture. Woda-ŚrodowiskoObszary Wiejskie. 9, 4 (28), 103, 2009 [In Polish]. 
29. GIOS. Full Information about the tasks of Inspection of Environmental Protection in 2010. 2013. http://www.gios. gov. pl/chemizm2010/index.html. Available on 20.10.2014, http://www.gios.gov.pl/zalaczniki/artykuly/Informacja_o_ realizacji_zadan_IOS_2013.pdf

30. Regulation of Minister of Agriculture and Rural Development, dated 11 III 2010, about minimal norms with subsequent amendments and other agricultural land. Journal of Laws No. 39, item 211.

31. Regulation (EC) No $2003 / 2003$ of the European Parliament and of the Council of 13 October 2003 relating to fertilizers. OJ L 304, 1, 21.11.2003.

32. MATYKA M. Trends in consumption of mineral fertilizers in Poland on the background of European Union. Roczn. Nauk. SERiA. 15 (3), 237, 2013 [In Polish].

33. JADCZYSZYN T., KOPIŃSKI J. Production and environmental aspects of nitrogen fertilization. Studia i Raporty IUNG-PIB. 34 (8), 27, 2013 [In Polish].

34. FILIPEK T., SKOWROŃSKA M. Current dominant causes and effects of acidification of soils under agricultural use in Poland. Acta Agrophysica, 20 (2), 283, 2013 [In Polish].
35. FOTYMA E., FOTYMA M., PIETRUCH Cz. Production and environmental effects of fertilization. Pam. Puł., 130, 179, 2002 [In Polish].

36. IGRAS J., LIPIŃSKI W. Regional diversification of agrochemical state of soils in Poland. Studia i Raporty IUNGPIB, 3, 71, 2006 [In Polish].

37. IGRAS J., KOPIŃSKI J., MATYKA M., OCHAL P. Consumption of mineral fertilizers in Poland by regions. Studia $i$ Raporty IUNG-PIB, 25, 9, 2010 [In Polish].

38. KOPIŃSKI J. Trends in the intensity of agricultural production in Poland in terms of environmental impact. Zesz. Nauk. SGGW, ser. Probl. Rol. Świat. 11 (4), 95, 2011 [In Polish].

39. KOPIŃSKI J., KRASOWICZ S. Regional differences in the conditions of agricultural production in Poland. Studia i Raporty IUNG-PIB. 22, 9, 2010 [In Polish].

40. SAPEK A., SAPEK B. Cycle and balance of phosphorus in human food chain in Poland. Fertilizers and fertilization. 4 (13), 105, 2002 [In Polish]. 